\title{
Who owns the news? The "right to be forgotten" and journalists' conflicting principles
}

\author{
Ivor Shapiro and Brian MacLeod Rogers
}

"The right to be forgotten" (RTBF) is a relatively new concept in human-rights law, but it deals in root ethical issues familiar to news people and their sources. Editors must routinely weigh the news' long-term role as a "historical record" against its potential negative impacts on individuals. In the digital-journalism era, publication is at the same time both more enduring and less static, creating new parameters and possibilities for ethical decision-making. Because news content may be seen by more people in more places for much longer, the potential to do lasting good or harm is greater, but, because digital publication is more retractable and redactible than legacy platforms, the possibility of correction, clarification and removal creates both new harm-reduction opportunities and new challenges to the historical record. Also known as a "right to erasure" or "right to oblivion," the RTBF, now accepted in the European Union, recognizes that, even in the age of Google, people should retain some degree of control over information about themselves and their pasts. (Factsheet on the 'Right to be Forgotten' ruling (C131-12), n.d.; Manna, 2014; Rosen, 2012). This paper will explore both legal and ethical implications of the issue.

\section{Birth of a legal right}

Data-protection regimes in Europe stem from a tradition, rooted in the Napoleonic Civil Code and bolstered by a visceral post-Fascist resistance to surveillance, of legally protecting autonomy over information about "the events of an individual life, both private and public" (Mantelero, 2013; Toobin, 2014). The European approach emphasizes human individual dignity, with corresponding rights and duties, whereas the common law treats privacy as a form of property right (Eltis, 2011). For example, the common law tort of "public disclosure of embarrassing private facts" by definition is not intended to protect a potential plaintiff against disclosure of facts that are in the public domain, such as a past criminal charge (Prosser, 1960).

Among common law countries, historically only the United States has given broad recognition to the tort of invasion of privacy, but it is balanced there by strong First Amendment rights for free speech and relaxed defamation laws. This tort in its various forms is becoming more accepted elsewhere in the common law, but Continental Europe has long exhibited a much greater degree of respect for private matters, even for those in public life. For example, it was a breach of criminal law to publish that the French President 
had an illegitimate daughter by a long-standing mistress, as was subsequently revealed about François Mitterand (Baume, 2012). This restriction on a free press would have been a non-starter in common law jurisdictions.

Article 12 of the European Community's 1995 Data Protection Directive allowed a person to require the "rectification, erasure or blocking" of unnecessary personal data ("Directive 95/46/EC" 1995). As the Community considered amendments to this directive -a process begun in 2012 and concluded in 2016 (European Commission - Justice, 2016) the contentious notion of RTBF emerged as a more robust recognition of individuals' desire to control their own information. False and defamatory statements could already be challenged through defamation laws, but not truthful facts-unless they crossed an unclear boundary into someone's "private and family life" (European Convention on Human Rights, Article 8.). The new idea of extending control over personal information was relatively easy to accept for information posted by the person on a public website, for example, especially for a youth. Similarly, there was little debate about third parties being held responsible for using personal information other than in the manner intended and agreed to by the individual. But proponents took the notion a step farther to encompass information that may have been appropriately published by others about the person.

Added to this respect for privacy interests came the notion of "redemption," allowing people to put their mistakes, even criminal ones, behind them in order to start anew-a principle that has been accepted in many jurisdictions, but most commonly for young offenders, who are allowed to escape the stigma of youthful indiscretions and crimes.

The seams between European and English legal cultures came into focus when English courts sought to apply the Convention to privacy concerns under common law, going beyond traditional breach-of-confidence case law to create a new tort for "misuse of private information" (Campbell v. MGN Limited [2004 UKHL 22], 2004, Google Inc v VidalHall \& Ors [2015] EWCA Civ 311, 2015, PJS v News Group Newspapers Ltd [2016] UKSC 26, 2016). The key issue for this tort is whether the disclosure amounts to a breach of one's "reasonable expectation of privacy". While this is not a subjective test, it is certainly one over which people differ, particularly as between national and cultural backgrounds. It directly calls into play boundaries for free expression, also protected under the Convention (Article 10), and requires a balancing of these rights - particularly where issues of public interest are involved.

Such a balance would become even tougher to find as information became more accessible thanks to Google. "God forgives and forgets but the Web never does," noted the European Commissioner when calling for rules "to better cope with privacy risks online" (Reding, 2010). This created the basis for the Commission's proposal for a RTBF that went beyond a "right to deletion or erasure" to what has been called "a right to oblivion" - that is, rather than applying only to self-published content or imposing acceptable time or usage limits on private data, access would now be blocked to information considered harmful and outdated even though true (Ambrose, 2014; McGoldrick, 2013; Xanthoulis, 2013). In 2014, however, the European Parliament trimmed the scope of the RTBF included in Article 17 of the General Data Protection Regulation to restrict its primary focus to the "right to erasure" (European Parliament, 2014).

It was against this background that the Grand Chamber of the Court of Justice of the European Union (CJEU) issued a dramatic ruling in 2014, applying the 1995 Directive to 
Google search results after the applicant had been unable to get a local newspaper to remove appropriately published articles from its own database (InfoCuria, 2014).

The CJEU upheld a Spanish court's order that Google Spain should remove links to 1998 reports in the Catalonian newspaper La Vanguardia about the forced sale of real estate in attachment proceedings against a Spanish man, Mario Costeja González, to settle his social security debts. The CJEU ruled that Google was a "controller" of personal data governed by the 1995 Directive and that the continued "processing" of personal data by search-engine operators, and the resulting ubiquity of search results, was "liable to affect significantly the fundamental rights to privacy and to the protection of personal data" when the individual's name was searched (Google Spain, para. 80).

The new right is by no means absolute; rather, the court mandated a three-way analysis, taking into account the rights of the subject, the economic freedom of the searchengine company, and the general public's legitimate interest in information, particularly where the subject may play a role in public life (Google Spain, para. 99). The court further suggested that information might have reduced significance as time goes on (para. 93), giving news, in effect, a "best-before" date, like yogurt.

Significantly, the court drew a clear distinction between search engines and website publishers with "solely ... journalistic purposes." Without a search-engine listing, the item on it original news web page becomes practically obscure, less likely to be stumbled upon, and thus less harmful. In 2016, Courts in Belgium and Italy ordered RTBF alterations to news archives, but at time of writing, these rulings currently apply only to their respective jurisdictions. (Matthews, 2016; Tomlinson, 2016).

In the wake of the Grand Chamber's decision, Google faced a deluge of requests for removal, and, after consulting a panel of expert advisors, it moved quickly to develop principles and practices for response. (Lomas, 2014; Report of the Advisory Council to Google on the Right to be Forgotten, 2015; Toobin, 2014) By May, 2017, Google had received 719, 327RTBF requests, and delisted 43.1 percent of the URLs evaluated as a result, although these URLs are, at time of writing, hidden only for searches conducted "from the country of the person requesting the removal." (Google Transparency Report, 2017)

In the United States, privacy concerns continued to be trumped by freedom of speech (Palm Beach Newspapers v. State of Florida, et. al., 2016). However, with pressure growing for European courts to impose worldwide limits that would apply to Google and other search engines subject to the courts' authority, Google pre-emptively decided to apply court orders in Europe to its worldwide algorithms, though only for searches initiated within the affected country (Keller, 2016). This step failed to satisfy the French regulator, but Google, arguing that France was imposing its rules on citizens of other countries, launched an appeal. This issue will clearly require involvement of the Court of Justice of the European Union, sometime after this writing (Conseil d'Etat, 2017; Dong, 2016; Roberts, 2015).

Some media organizations responded assertively to RTBF deletions either by publishing the fact of these deletions or republishing items that had been deleted (Lee 2015; “Pink News Republishes Stories Removed”' 2016). While further appeals to data protection agencies can be undertaken, as occurred in the Costeja case, the volume of requests has meant that Google itself has become the key arbiter in enforcing the law. Nor has Europe's 2016 data-protection regulation clarified whether social-media platforms 
such as Facebook and Twitter will be subject to future RTBF orders (European Commission - Justice, 2016; Keller, 2015).

Nevertheless, the RTBF seed has been firmly planted in European law, with seemingly inevitable international repercussions and implications for journalistic practice, as we will show in the remainder of this paper.

\section{A clash of ethical principles}

The roots of all law lie in ethics: legislation and the common law codify a society's perceived consensus on rights and wrongs, and courts then apply those principles to life specific situations. In other words, the law seeks to codify and enforce a society's consensus on values and mediate conflicting values. Señor Costeja, for example, was far from the first person to express a desire to assume some control of information about his past life, and news people are familiar with the ethical essence of the Costeja quandary - a conflict between the duty to provide a lasting record and the expression of ordinary humanity in mitigating harm.

The "right to privacy" clearly implies a reciprocal duty for people not to know certain types of information about one another, or, if they do, to resolve pragmatically to "forget" it - a decision that is increasingly difficult to apply in the digital age (Matheson, 2013:197,202; see also Mayer-Schönberger, 2009). While the rules of court proceedings routinely expect judges and juries to "forget" information not in evidence, and that fiduciary duty can also apply to others (for example, teachers who suspect a student of cheating but lack solid evidence), it is another thing altogether to impose a duty of forgetfulness on society at large through selective erasure of its digital memory bank.

The moral right at the heart of this quandary is more accurately expressed as a right to obscurity (Hartzog and Selinger, 2015) or, as styled by some Italian courts, oblivion "the right of any individual to see himself or herself represented in a way that is not inconsistent with his/her current personal and social identity" (Manna, 2014). Even if total control of one's universal online profile were desirable in public policy - allowing for digital oblivion - it would be an unrealistic goal (Fazlioglu, 2013; Rosenzweig, 2012). More realistic is the idea of relative obscurity, a circumstance-limited right which, like freedom to express oneself, derives from autonomy: the right to make the choices that drive one's life, including whether to draw attention to oneself, or to remain quiet (Ausloos, 2012; Baker, 2004; LaRue, 2011). Similarly, the jurisprudence on both defamation and hate speech asserts the importance of people's ability to retain control of their own lives or to participate in democratic society. Individuals' rights (such as the expression of provocative opinions) are, famously, limited by the social contract itself: incitement to racial violence, for example, is not protected. Autonomy rights are, therefore, limited by the conflicting attributes of a situation; for example, someone who may normally enjoy private-citizen status may later become a public figure, making information about their past important to the public interest.

\section{'Unpublishing' and the right to privacy}

The relativistic nature of autonomy rights has important practical limitations with respect to availability of information. All the courts that broke ground in Costeja were 
careful to distinguish the continued availability of news articles in news organizations' online archives (Glasser, 2014; Tomlinson, 2015). Likewise, journalists have traditionally resisted the idea of "unpublishing" - the retrospective redaction of error-free news reports.

In recent years, however, news organizations have received increasing numbers of requests to adjust their digital records in this way, and there are signs that, rather than dismiss these out of hand, many are seeking a way to achieve consistency and fairness (Brock, 2016: 87-88; Edmonds, 2016; Pantic, 2014: 18; Watson, 2012). As with Costeja, negative and long-past involvements with the law represent a significant proportion of news sources' attempts to refine their online identity, a concern also evidenced by the sporadic success of unscrupulous website operators who post, and then offer to delete for a fee, accused criminals' mug shots or court reports (Dobby, 2015; Segal, 2013). Nor is it surprising or unreasonable that previously accused people try to clean up the reporting of criminal charges retrospectively; crime reporting is notoriously episodic and often left unfinished in the public record (Andrews, 2014; Kauth, 2015).

Editors have responded to such requests in a variety of ways, depending on both inclination and circumstances - these forms of response include wholesale granting or refusal of the request, removing a source's name while leaving the article otherwise intact, inserting an addendum or correction, generating a follow-up story, and removing stories from Google's cache (Tenore, 2010). However, North American editors surveyed by English in 2009 mostly rebuffed the need for consistent policies on unpublishing, stating that news organizations "do not rewrite history; we report what happened," and, "Sorry, life isn't fair. Journalism's job isn't to clean up your driving record so you can get a job, is it?". They conceded that content should be removed online under "very rare circumstances," including where required by libel or other legal requirements. "Serious consideration to an unpublishing request should also be given when someone's life may be endangered," English concluded (English, 2009).

Five years after this survey, relatively few news organizations appeared to have implemented comprehensive policies as to how to respond to these requests, preferring case-by-case adjudication of requests (Pantic, 2014: 52,85). A panel report for the Canadian Association of Journalists' ethics advisory committee, revisited the committee's earlier stated position that journalists "are in the publishing business and generally should not unpublish". The panel reconstructed a case where a newspaper granted an unpublishing request, and suggested that it might be time for journalists to "reassess their attribution practices," with growing openness to offering anonymity, in order to prevent long-term harm to people who volunteer information about "profoundly personal" situations (Currie and Brethour, 2014; English et al., 2010). More recently, there have been signs of a growing appetite to try to codify an approach to resolving these requests (Edmonds, 2016). Some of these requests have become quite nuanced; in one instance, a person asked that Canada's CBC network merely remove his name from an online headline; the request was denied, but the network's ombud, clearly troubled, wrote that the unpublishing issue "requires nuanced and ongoing consideration" (Enkin, 2016).

To describe the discussions around these issues as a direct clash between the right of free expression and that of privacy is to dramatically oversimplify the questions involved. Rather, applying a right to obscurity would involve weighing several social values, including freedom of information and the integrity of historical research (Manna, 2014). Viewed under this more nuanced lens, the arguments surrounding unpublishing 
expose no fewer than six ethical principles. Three of these principles would tend to foster continuity of publication, even of potentially harmful material, while an equal number tend in the opposite direction.

First among the three pro-continuity principles is that free expression should be defended (Weber, 2011). To allow people in the news to exert influence over what should be (or remain) published flies in the face of the essence of press freedom, which rests to some extent on a news culture of being "unconstrained by the long view or deep understanding," an independence of mind that mitigates such clearly undesirable constraints as dependency on "conventional wisdom" and on official and professional sources (Schudson, 2005: 24-26).

Second, publication continuity is supported by the idea that information in its original form ought to be protected for the sake of historical integrity. This is an uncomfortable principle, and not only insofar as it touches on news reports: why should an individual's divorce-court affidavit or contractual dispute become someone else's business in the future? But for historians, these documents provide insight into trends and issues plus, character-revealing details about today's obscure individual could be of considerable public interest when that person assumes a more public role in the future.

The third principle is that of accountability. Journalism is made credible by the verifiable and falsifiable details that back up reports; for this reason, journalists tend to prefer named sources to veiled ones (Gladney et al., 2013: 36-37; Vultee, 2010). Shafer is far from alone in advising readers to "discount anything a shadowy unknown source is allowed to say in a news story" (Shafer, 2014). This principle is undermined when a person's name is removed from the online version of a news article.

Turning to principles that tend to constrain publication, the first and most familiar is the idea of harm reduction. In media ethics codes, this idea has classically been applied to children and other vulnerable subjects, and to the right to a fair trial. It has guided practice in preventively veiling the identity of whistleblowers and sexual-assault victims. As parents watch their children's digital lives causing more than mere embarrassment, it may become harder to resist efforts to provide people with means of erasing the public record - efforts that, once acquiring momentum, are likely to sweep routine news reports into the same unsavoury box as sex videos and careless tweets (Ohm, 2015).

A second such principle is respect for privacy, which Moore defines as "a right to control access to and uses of places, bodies, and personal information" (Moore, 2008: 421). News people do not normally delve into adoption records, sexual matters and personal financial records without some clear public-interest justification. Indeed, "without strong privacy safeguards, it becomes far more difficult [...] for people to exercise their human right to free expression. It is an established fact that when people believe they're being watched, their behaviour changes in very significant ways" (Christopher, 2015). In the discussions surrounding "big data," an emerging principle is that the collection of data is unobjectionable so long as the information is not individualized (Francis and Francis, 2014). Search engines and news reports, however, individualize data almost by definition.

Less commonly associated with media ethics is the aforementioned idea of redemption. The idea that people should generally be able to put past transgressions behind them and move forward is expressed in the idiomatic idea of "forgive and forget," and the law in some countries allows people's criminal records to be expunged after sufficient time has passed (Bennett, 2012: 166-167). Laws and regulations in the United 
States, for example, afford individuals the opportunity to "move on" and get a "second chance" following bankruptcies, juvenile criminal behavior, and credit reporting (Blanchette and Johnson, 2002: 4; Jones et al., 2012). Ubiquitous search results butt against this principle.

How may these conflicting principles be reconciled? Because this task - weighing conflicting principles against each other - is substantially similar in ethical reflection as in human-rights jurisprudence, it may be helpful to look again at the European Court's argumentation in Costeja.

\section{Two important distinctions}

Stripped of legal foundations and arguments, the Grand Chamber's decision rested on two epistemological distinctions that, in our view, may also help journalists to begin resolving the above-described conflict between principles that tend to foster continuity and those that challenge it.

First, the court drew a clear distinction between truthfulness and "relevance." While there is no stale-date on accuracy, relevance is situational and, therefore, temporary. Often, this principle is expressed with reference mainly to the passage of time. The idea of newsworthiness itself - starting with the very word "news" - may be seen as suggesting that old stories (yesterday's news) are less relevant than current ones (Potter, 2009: 5). Yet, relevance is not adequately measured in days or years; it may or may not diminish with the passage of time. While the Amsterdam Court of Appeal ruled that negative publicity caused by a criminal offence continues to be "relevant" information even if time elapses, the Dutch Supreme Court, on appeal, instructed that the Costeja principles should be applied (van den Brink, 2017). Were a 40-year-old news report to be discovered, quoting a current political leader as expressing vile racist views, that country's citizens might well consider the old report "relevant". Indeed, while timeliness is often cited as an element of "newsworthiness," additional elements are always present, often including prominence, proximity and probable impact (Schultz, 2007). Where U.S. courts have weighed in on an item's "newsworthiness," they have tended to probe factors such as public concern, undue offensiveness, and whether or not journalists have pursued it with morbid fascination or recklessness (McNealy, 2012).

The second important distinction is, as mentioned above, that between the mere availability of information and its being instantly "findable". A functionally infinite searchfacilitator, such as Google, imposes a level of scrutiny over past acts that seems, to some, less preferable to a "balance between the protection of the individual memory and the rights to information for citizens" (Salarelli, 2015) .

When these distinctions are applied to unpublishing requests, some of the three pro-continuity principles might wane in force.

Free speech significantly predates the existence of Google, and a news organization's freedom to choose what to report and publish also allows it to choose what not to publish and, by extension, when to hide certain text from search engines for good reason. Even if not easily "findable," the original report may remain available digitally, either in PDF archives or on stored web-page archives such as the Wayback Machine at archive.org (Lepore, 2015), or through other creative workarounds to conventional delisting (Renner, 2016). Thus, compassionate deletion from a news website and from Google's cache should 
not require material to be unpublished from newspapers' databases. Unpublishing, in other words, need not involve an all-or-nothing decision.

Turning to accountability, the persuasiveness and credibility of a news report is primarily a consideration with a view to contemporaneous readers; as time goes by, the reader will have alternative and, perhaps, more reliable means to get at the truth. Indeed, if the original report, seen in isolation, provides a potentially distorted or inaccurate lens on the whole truth, then the idea of "relevance" - that is, practical usefulness to the reader would favor the provision of a cleaner, contextualized record. The "relevance" principle hardly requires the outright deletion of a news item, but the primary journalistic responsibility of seeking accuracy is widely acknowledged as obliging a news organization to correct the facts in an original item's digital manifestation. So, at the very least, reports of criminal charges that led to acquittal should be updated, where the accused is identified, in the name of proportionality and context (Brock, 2016: 88).

The argument for historical integrity is harder to shrug off. When the Toronto Star unpublished a discredited article about vaccine safety in February, 2015, the article did not merely disappear from Google searches (Braganza, 2015); it disappeared from full-text library databases as well. The disappearance of a published work from libraries sends a Big Brother-esque chill up the free-information spine, and the test of "relevance" may be fickle: information about a 25-year-old law student's conduct might seem highly relevant to informed public debate (the most critical purpose of free expression itself) when he is later up for appointment as judge or attorney general.

The arguments above suggest strong justification for adopting a reasonably fluid approach to corrections and clarifications to the published record, with a view to ongoing care for accuracy, contextualization and completeness. But when it comes to unpublishing, as opposed to transparent revision, the difference between availability and "findability" may be tough to nail down. A credible argument may be made that by today's standards, a piece of information that's absent from Google results may as well, for practical purposes, be under lock and key: it will only be found by those who know enough to search for it. It is hard to accept this kind of informational vanishing act without coming close to a generalized social "duty to forget."

With or without a RTBF, then, the idea of unpublishing remains no less complex than the pre-publication balancing acts often involved in responsible journalism itself. Journalists do not merely collect and disseminate information: they are routinely expected to add edificatory and evaluative content encompassing independent discovery, verification, and interpretation (Shapiro, 2014). It does not seem a stretch to argue that these responsibilities continue after publication in correcting the record. News content is, by nature temporally conditioned, a "partial, hasty, incomplete, inevitably somewhat flawed and inaccurate rendering of some of the things we have heard," in the famous words of Washington journalist David Broder (Lewis and Crick, 2014: 59). Any work of journalism is thus subject to later addition or correction by other journalistic work that may or may not be assigned within or beyond the original news organization, according to highly subjective, even random, decisions on what constitutes "news" on any given day (Carey, 1987: 151). If weighing harm is already an accepted part of journalistic considerations under some circumstances, then it would be difficult to exempt from further consideration the somewhat arbitrary post-publication routine of deciding what is or is not subject to correction or amplification. 


\section{The autonomy of news subjects: signs of a shift}

Moving beyond the adjudication of unpublishing requests, growing awareness of the so-called longtail of news is subtly altering discourse about the exercise of journalists' ethical discretion before publication. In the United States, a 2014 update of the Society of Professional Journalists' code called for journalists to "consider the long-term implications of the extended reach and permanence of publication" (Society of Professional Journalists, 2014). One investigative journalist described to a journalism class taught by us how he had carefully explained to a woman the possible consequences of broadcasting her on-camera confession of having used cocaine in the presence of her child. In another class for the same group of graduate students, a different reporter said he and a colleague had decided to include a video of a criminal act, showing the face of the alleged perpetrator, but decided against including that person's full name in the written report. Their grounds for doing so: a face on video will not show up in name-based search results.

It will surely remain unusual for such consideration to be shown to a criminal caught in the act, and the danger of a slippery slope is worth marking. Journalism's independence is well served by a culture of favouring audiences' desire for information over potential benefit or harm to people in the news. The innate tension between this culture and the exercise of caution with respect to potential harm is, perhaps, an argument for shifting the adjudication of difficult questions from the subjective realm of journalists' impulses to the public realm of guidelines and debate (Ward, 2014). Guidelines based on categories of situation types, as proposed in a more general context by Hartzog and Selinger (2015), may help resolve most matters, while unavoidably leaving others in grayer moral zones. Even within those areas of uncertainty, journalists would probably prefer to see themselves as better placed to make tough judgments than the alternative deciders courts and governments. In Canada, for example, it would take but a small stroke of Parliament's pen to amend the Personal Information Protection and Electronic Documents Act (S.C. 2000, c.5), to remove Section 7(1)(c), which exempts journalistic research from the prohibition on unauthorized collection of private information.

One way to proactively avoid tough RTBF requests would be more scrupulous attention to follow-up on crime stories, especially where an acquittal follows a charge. It will be increasingly difficult for journalists to make a convincing case for maintaining the integrity of a historical record when the historical record is blatantly and damagingly incomplete (Andrews, 2014; Brock, 2016: 88; Segal, 2011). However, it seems inevitable that increased consciousness of news coverage's longevity will foster a willingness by journalists to consider granting to their subjects, as Kennamer and Gillespie have suggested, a similar level of autonomy as is enjoyed by the subjects of scientific research, under guidelines that guard against needless deception, and recognize subjects' vulnerability to exploitation (Gillespie, 2009; Kennamer, 2005). The idea of informed consent is not traditionally part of journalists' parlance, but why would a morally aware journalist not show consideration toward ordinary citizens who might not be "equipped with the proper level of media literacy skills in order to manage the responsibility for their own privacy" (Nina and Boers, 2013)? The authors of a Canadian ethics panel report failed to reach agreement on journalists' obligations when it comes to informed consent, but did suggest that news organizations offer more guidance to journalists regarding consent protocols (Enkin, 2014; Levine et al., 2014). As one of the authors put it: 
journalists do engage in discussions about consequences with potential subjects and sources all the time, but we tend to keep those conversations focused on the potentially positive things[....] Perhaps the time has come to include acknowledgment, in the limited circumstances outlined above, of [...] some of the potential risks. (Levine et al., 2014: 14)

Indeed, it might even be argued that journalists have an implicit contractual duty to use information only in ways that are consistent with the intent of the source (Walker, 2012). In effect, journalists make a business arrangement with their sources for the disclosure and transmission of information, and any such arrangement is subject to the conditions to which both parties explicitly, or implicitly, agree. Where the conditions of that arrangement are ambiguous, one party is likely to be unfairly disadvantaged. Journalists might find such ambiguity convenient, but it is hard to imagine a moral principle on the basis of which their convenience should trump others' rights to autonomy over their own future. In some cases, that includes "resetting their digital life" (Brock, 2016: 86). In an age of infinite information longevity, it seems reasonable to accommodate moderate limits on public memory.

\section{RECOMMENDED READING}

Jeffrey Toobin's "The Solace of Oblivion," in the New Yorker (2014), provides an engaging look into the consequences of Europe's Right to be Forgotten ruling, a complete (and equally readable) analysis of which may be found in George Brock's The Right to Be Forgotten: Privacy and the Media in the Digital Age (2016). Turning from the law to moral choices, the Canadian Association of Journalists' ethics advisory committee provided relevant guidance and context in two 2014 panel reports: by Currie and Brethour on unpublishing, and by Levine, English and Enkin on informed consent.

\section{REFERENCES}

Ambrose, M. L. (2014) "Speaking of forgetting: Analysis of possible non-EU responses to the right to be forgotten and speech exception." Telecommunications Policy 38(8-9), 800-811.

Andrews, P. (2014) "Publishing the start and finish of crime stories." Guelph Mercury (Guelph, Ontario), 22 February.

Ausloos, J. (2012) "The 'right to be forgotten' - worth remembering?" Computer Law \& Security Report 28(2), 143.

Baker, C. E. (2004) "Autonomy and informational privacy, or Gossip: The central meaning of the First Amendment." Social Philosophy and Policy 21(2), 215-268.

Baume, M. D. L. (2012) "Mazarine Pingeot, Mitterrand daughter, looks back." The New York Times, 30 November. Retrieved from: 
http://www.nytimes.com/2012/12/01/world/europe/mazarine-pingeotmitterrand-daughter-looks-back.html

Bennett, S.C. (2012) "The 'right to be forgotten': Reconciling EU and US perspectives." Berkeley Journal of International Law 30(1), 161-195.

Blanchette, J.-F. and Johnson, D.G. (2002) "Data retention and the panoptic society: The social benefits of forgetfulness." The Information Society 18(1), 33-45.

Braganza, C .(2015) "The Toronto Star's Gardasil controversy: A timeline." J-Source. Retrieved from: http://j-source.ca/article/toronto-stars-gardasil-controversytimeline

Brock, G. (2016) The Right to Be Forgotten: Privacy and the Media in the Digital Age. London: I.B.Tauris.

Campbell v. MGN Limited [2004 UKHL 22] (2004). Retrieved from: http://www.publications.parliament.uk/pa/ld200304/ldjudgmt/jd040506/campb e-1.htm

Carey, J. W. (1987) "Why and how: The dark continent of American journalism. In R.K. Manoff and M. Schudson (eds.) Reading the News. New York: Pantheon Books (pp. 146-196).

Christopher, D. (2015) "True free expression requires privacy." Canadian Journalists for Free Expression. Retrieved from: https://cjfe.org/resources/features/true-freeexpression-requires-privacy

Conseil d'Etat (2017) "Right to be delisted." Retrieved from: http://english.conseiletat.fr/Activities/Press-releases/Right-to-be-delisted

Currie, T. and Brethour, P. (2014) "Case study and analysis on unpublishing. [A report of the Ethics Advisory Committee of the Canadian Association of Journalists.]" J-Source. Retrieved from: http://www.j-source.ca/article/caj-ethics-committee-case-studywhen-unpublish

Dobby, C. (2015) "Canadians upset with Romanian website that exposes court case details." The Globe and Mail, 4 January. Retrieved from:

http://www.theglobeandmail.com/report-on-business/industry-news/the-lawpage/canadians-upset-over-romanian-website-that-exposes-court-casedetails/article22284367/

Dong, K. (2016) "News: Google takes a new approach to the 'right to be forgotten' in response to regulator pressure." Inforrm's Blog. Retrieved from: https://inforrm.wordpress.com/2016/03/10/news-google-takes-a-new-approachto-the-right-to-be-forgotten-in-response-to-regulator-pressure/ 
Edmonds, R. (2016) "Newspapers hit with a wave of requests to take down embarrassing archived stories." Poynter. Retrieved from:

http://www.poynter.org/2016/newspapers-hit-with-a-wave-of-requests-to-takedown-embarrassing-archived-stories/432585/

Eltis, K. (2011) "Breaking through the 'Tower of Babel': A 'right to be forgotten' and how trans-systemic thinking can help reconceptualize privacy harm in the age of analytics." Fordham Intellectual Property, Media \& Entertainment Law Journal 22(1): 69.

English, K. (2009) The Longtail of News: To unpublish or not to unpublish. Online Journalism Credibility Projects, Associated Press Managing Editors. Retrieved from: http://www.apme.com/?Unpublishing

English K., Currie, T. and Link, R. (2010) "The ethics of unpublishing. [A report of the Ethics Advisory Committee of the Canadian Association of Journalists]." J-Source. Retrieved from: http://j-source.ca/article/ethics-unpublishing

Enkin, E. (2014) "On the record: Is it really consent without discussion of consequences?" JSource. Retrieved from: http://www.j-source.ca/article/record-it-really-consentwithout-talk-consequences

------- (2016) "Public record vs. right to be forgotten". CBC Ombudsman. Retrieved from: http://www.ombudsman.cbc.radio-canada.ca/en/complaint-reviews/2016/publicrecord-vs-right-to-be-forgotten/

European Commission - Justice (2016) Protection of personal data. Retrieved from: http://ec.europa.eu/justice/data-protection/

European Parliament (2014) Protection of individuals with regard to the processing of personal data. Retrieved from: http://www.europarl.europa.eu/sides/getDoc.do?pubRef=-//EP//TEXT+TA+P7TA-2014-0212+0+DOC+XML+V0//EN

Factsheet on the 'Right to be Forgotten' ruling (C131-12) (n.d.) European Commission. Retrieved from: http://ec.europa.eu/justice/dataprotection/files/factsheets/factsheet_data_protection_en.pdf

Fazlioglu, M. (2013) "Forget me not: The clash of the right to be forgotten and freedom of expression on the Internet." International Data Privacy Law 3(3): 149.

Francis, J.G. and Francis, L.P. (2014) "Privacy, confidentiality, and justice." Journal of Social Philosophy 45(3): 408-431.

Gillespie, B. (2009) "Journalists and their sources: A critical examination of ethics in conventional journalism methodology." M.A. thesis, Integrated Studies, Athabasca University. Retrieved from: 
http://dtpr.lib.athabascau.ca/action/download.php?filename=mais/BruceGillespie Project.pdf

Gladney G.A., Shapiro, I. and Ray, R. (2013) Reasons for veiled sources spike after 2004 scandals. Newspaper Research Journal 34(2): 36-49.

Glasser, C.J. (2014) "Christmas arrives early for newsrooms: EU Privacy Working Group says newspapers' search engines are not subject to RTBF." MLRC Bulletin, December.

Google Inc v Vidal-Hall \& Ors [2015] EWCA Civ 311 (2015). Retrieved from: http://www.bailii.org/ew/cases/EWCA/Civ/2015/311.html.

Google Transparency Report (2017) "European privacy reports for search removals." Retrieved from: https://www.google.com/transparencyreport/removals/europeprivacy/?hl=en

Hartzog, W. and Selinger, E. (2015) "Google's action on revenge porn opens the door on right to be forgotten in US." The Guardian. Retrieved from: http://www.theguardian.com/technology/2015/jun/25/googles-revenge-pornopens-right-forgotten-us

InfoCuria (2014) Google Spain SL, Google Inc. v. Agencia Española de Protección de Datos (AEPD), Mario Costeja González ECLI:EU:C:2014:317. Retrieved from: http://curia.europa.eu/juris/document/document.jsf;jsessionid=9ea7d2dc30dd22f 58fa149c7444d8a018188ebb3b432.e34KaxiLc3qMb40Rch0SaxuPah10?text=\&doci $\mathrm{d}=152065$ \&pageIndex=0\&doclang=en\&mode=lst\&dir=\&occ=first\&part=1\&cid=210 401.

Jones, A., Leta, M., Friess, N., et al. (2012) Seeking Digital Redemption: The Future of Forgiveness in the Internet Age. SSRN Scholarly Paper, Rochester, NY: Social Science Research Network. Retrieved from: http://papers.ssrn.com/abstract=2154365

Kauth, G. (2015) "Lingering media coverage a growing issue for defence lawyers." Law Times, 5 January. Retrieved from: http://lawtimesnews.com/201501054390/focuson/focus-lingering-media-coverage-a-growing-issue-for-defence-lawyers

Keller, D. (2015) "The final draft of Europe's 'Right to Be Forgotten' law." The Center for Internet and Society. Retrieved from: http://cyberlaw.stanford.edu/blog/2015/12/final-draft-europes-right-beforgotten-law

------ (2016) "Global right to be forgotten: Delisting, why CNIL is wrong." Inforrm's Blog. Retrieved from: https://inforrm.wordpress.com/2016/11/22/global-right-to-beforgotten-delisting-why-cnil-is-wrong-daphne-keller/

Kennamer, D. (2005) "What journalists and researchers have in common about ethics." Journal of Mass Media Ethics 20(1): 77-89. 
LaRue, F. (2011) Report of the Special Rapporteur on the promotion and protection of the right to freedom of opinion and expression. Human Rights Council, United Nations. Retrieved from:

http://www2.ohchr.org/english/bodies/hrcouncil/docs/17session/A.HRC.17.27_e n.pdf

Lee, D. (2015) "BBC forgotten list 'sets precedent'." BBC News. Retrieved from: http://www.bbc.com/news/technology-33287758

Lepore, J. (2015) "The cobweb: What the Web said yesterday. The New Yorker. Retrieved from: http://www.newyorker.com/magazine/2015/01/26/cobweb

Levine, M., English, K., Enkin, E., et al. (2014) "On the Record: is it really consent without discussion of consequences? [A Report of the Ethics Advisory Committee of the Canadian Association of Journalists]." J-Source. Retrieved from: http://jsource.ca/article/informed-consent

Lewis, J. and Crick, P. (2014) Media law and ethics in the 21st century: Protecting free expression and curbing abuses. London: Palgrave Macmillan.

Lomas, N. (2014) "Google starts granting 'right to be forgotten' requests in Europe." Techcrunch. Retrieved from: http://techcrunch.com/2014/06/26/right-to-beforgotten-is-go/

Manna, L. (2014) "The right to oblivion, right of information and the Internet: An overview of Italy's current trends." Lexology. Retrieved from: http://www.lexology.com/library/detail.aspx?g=ffc522d4-6d26-4b82-9563ca633c9e9442

Mantelero, A. (2013) "The EU proposal for a General Data Protection Regulation and the roots of the 'right to be forgotten'." Computer Law and Security Review: The International Journal of Technology and Practice 29(3): 229-235.

Matheson, D. (2013) "A duty of ignorance." Episteme 10(2): 193.

Matthews, A. (2016) "How Italian courts used the right to be forgotten to put an expiry date on news." The Guardian, 20 September. Retrieved from: https://www.theguardian.com/media/2016/sep/20/how-italian-courts-used-theright-to-be-forgotten-to-put-an-expiry-date-on-news.

Mayer-Schönberger, V. (2009) Delete: The Virtue of forgetting in the digital age. Princeton University Press.

McGoldrick, D. (2013) "Developments in the right to be forgotten." Human Rights Law Review 13(4): 761. 
McNealy, J. (2012) "The Emerging conflict between newsworthiness and the right to be forgotten." Northern Kentucky Law Review 39(2): 119-135.

Moore, A. (2008) "Defining privacy." Journal of Social Philosophy 39(3): 411-428.

Nina, Ñ. and Boers, R. (2013) "Disliking the like." New Library World 114(7/8): 319-325.

Official Journal L 281, 23/11/1995 P. 0031 - 0050 (1995) Directive 95/46/EC of the European Parliament and of the Council of 24 October 1995 on the protection of individuals with regard to the processing of personal data and on the free movement of such data. Retrieved from: http://eurlex.europa.eu/LexUriServ/LexUriServ.do?uri=CELEX:31995L0046:en:HTML

Ohm, P. (2015) "Sensitive information." Southern California Law Review 88(5): 1125.

Palm Beach Newspapers v. State of Florida, et. al. (2016). Retrieved from: http://cjrarchive.org/img/posts/Post\%20DCA\%20opinion\%20(1).pdf

Pantic, N. (2014) "Gatekeeping and unpublishing: How editors make publishing and unpublishing decisions." M.A. thesis, University of Missouri - Columbia. Retrieved from: http://gradworks.umi.com/10/18/10181057.html

PJS v News Group Newspapers Ltd [2016] UKSC 26 (2016). Retrieved from: https://www.supremecourt.uk/cases/uksc-2016-0080.html

Potter, D. (2009) Handbook of Independent Journalism. Orange Grove Books. Retrieved from: https://www.free-ebooks.net/ebook/Handbook-of-Independent-Journalism

Press Gazette (2016) "Pink News republishes stories removed from Google search results under 'right to be forgotten'." Retrieved from: http://www.pressgazette.co.uk/pinknews-republishes-stories-removed-from-google-search-results-under-right-to-beforgotten/

Prosser, W. (1960) "Privacy." California Law Review 48(3): 383.

Reding, V. (2010) "Privacy matters: Why the EU needs new personal data protection rules." European Commission Press Release Database. Retrieved from: http://europa.eu/rapid/press-release_SPEECH-10-700_en.htm

Renner, N. (2016) "A loophole in the right to be forgotten." Columbia Journalism Review. Retrieved from: http://www.cjr.org/tow_center/loophole_google_right_forgotten.php

"Report of the Advisory Council to Google on the Right to be Forgotten" (2015). Retrieved from:

https://drive.google.com/file/d/0B1UgZshetMd4cEI3SjlvV0hNbDA/view?pref=2\&p li=1\&usp=embed_facebook 
Roberts, J. J. (2015) "Google defies France over 'right to be forgotten'." Fortune. Retrieved from: http://fortune.com/2015/07/30/google-france-right-to-be-forgotten/

Rosen, J. (2012) "The right to be forgotten." Stanford Law Review Online 64: 88-92.

Rosenzweig, P. (2012) "Whither privacy?" Surveillance \& Society 10(3/4): 344-347.

Salarelli, A (2015) "The right to be forgotten: What changes after the European Court of Justice judgment against Google." Italian Journal of Library, Archives, and Information Science (JLIS.it) 6(1): 147-160.

Schudson, M. (2005) "The virtues of an unlovable press." The Political Quarterly 76: 23-32.

Schultz, I. (2007) "The journalistic gut feeling." Journalism Practice 1(2): 190-207.

Segal, C. (2011) "Is follow-up required on campus police blotter reports? Scholars speak out." iMediaEthics. Retrieved from: http://www.imediaethics.org/is-follow-uprequired-on-campus-police-blotter-reports-scholars-speak-out/

Segal, D. (2013) "Mug-Shot websites, retreating or adapting." New York Times, 10th November.

Shafer, J. (2014) "The source may be anonymous, but the shame is all yours." Reuters. Retrieved from: http://blogs.reuters.com/jackshafer/2014/06/16/the-source-maybe-anonymous-but-the-shame-is-all-yours/

Shapiro, I. (2014) "Why democracies need a functional definition of journalism now more than ever." Journalism Studies 15(5): 555-565.

Society of Professional Journalists (2014) "SPJ Code of Ethics." Available from: http://www.spj.org/ethicscode.asp

Tenore, M.J. (2010) "5 ways news organizations respond to 'unpublishing' requests." Poynter. Retrieved from: https://www.poynter.org/2010/5-ways-newsorganizations-respond-to-unpublishing-requests/104414/

Tomlinson, H. (2015) "Case Law, Spain: A and B v Ediciones El Pais, Newspaper archive to be hidden from internet searches but no 're-writing of history.'" Inforrm's Blog. Retrieved from: https://inforrm.wordpress.com/2015/11/19/case-law-spain-aand-b-v-ediciones-el-pais-newspaper-archive-to-be-hidden-from-internet-searchesbut-no-re-writing-of-history-hugh-tomlinson-qc/ (2016) "Case Law, Belgium: Olivier G v Le Soir. 'Right to be forgotten' requires anonymisation of online newspaper archive." Inforrm's Blog. Available from: https://inforrm.wordpress.com/2016/07/19/case-law-belgium-olivier-g-v-le-soirright-to-be-forgotten-requires-anonymisation-of-online-newspaper-archive-hughtomlinson-qc/ 
Toobin, J. (2014) "The solace of oblivion." The New Yorker 90 (29): 26-32 .

van den Brink, J. (2017) "Media report : Missed opportunity - Dutch Supreme Court copypastes Google Spain judgment. Media Report: Kennedy Van der Laan Attorneys. Retrieved from: http://www.mediareport.nl/en/press-law/25042017/missedopportunity-dutch-supreme-court-copy-pastes-google-spain-judgment-2/

Vultee, F. (2010) "Credibility as a strategic ritual: The Times, the interrogator, and the duty of naming." Journal of Mass Media Ethics 25(1): 3-18.

Walker, R. K. (2012) "The right to be forgotten." Hastings Law Journal 64(1): 257.

Ward, S. J. A. (2014) "Why new journalism ethics have to be public, not personal." MediaShift. Retrieved from: http://mediashift.org/2014/10/why-new-journalismethics-have-to-be-public-not-personal/

Watson, D. (2012) "Unpublishing requests are on the rise." Columbia Journalism Review. Retrieved from: http://www.cjr.org/the_news_frontier/unpublishing_requests_are_on_t.php

Weber, R.H. (2011) "The right to be forgotten." JIPITEC : Journal of Intellectual Property 2: 120-130.

Xanthoulis, N. (2013) "The right to oblivion in the information age: a human-rights based approach." US-China Law Review 10: 84. 